\title{
Competencies and curricula: Two case stories of two-dimensional curriculum development
}

\author{
Tomas Højgaard ${ }^{1}$ and Jan Sølberg ${ }^{2}$ \\ ${ }^{1}$ Danish School of Education, Aarhus University, Aarhus, Denmark \\ 2,Department of Science Education, University of Copenhagen, Denmark \\ For correspondence: tomas@edu.au.dk
}

\begin{abstract}
Curricula around the world make more and more use of goals trying to capture different kind of processes for the students to master. In Denmark these ambitions have most recently been described in terms of subject specific competencies. However, bringing such ambitions into the actual teaching practices has proved challenging. KOMPIS was a longitudinal project aimed at developing and examining ways of dealing with some of these challenges in lower secondary Danish classrooms in collaboration with teachers. In this paper, we present aspects relevant to mathematics and science curricula. As a key point of this analysis we present a two-dimensional content model derived from KOMPIS that proved useful in supporting competence-based curriculum development and teacher planning. We argue that curriculum descriptions of competency objectives need to be clear and distinct as well as independent of subject matter to be operational.
\end{abstract}

Keywords: Competence; mathematical competencies; science competencies; the KOMPIS project; twodimensional content framework

\section{Introduction}

KOMPIS was a longitudinal research and development project conducted in the years 2009-2012. The project was based on collaboration between teachers, teacher educators and researchers working to implement competency-oriented teaching in mathematics, science and Danish language classes for grades 7-9. The results of the collaboration included the development and testing of models, concepts and teaching practices emerging from ongoing experiments with competency-oriented teaching (cf. the previously published papers Højgaard et al., 2010 and Sølberg et al., 2015, written for a Danish audience, from which this paper contains translated and edited excerpts). A number of these model and concepts were subsequently incorporated into the national curriculum between the years 20132018.

In this paper, we will focus on the curricular aspects of the KOMPIS project within the subjects of mathematics and science by analysing the following question: How can we describe curriculum in a way that enables teachers to structure their planning in a manner that focusses on student competence? Firstly, the background for and history of KOMPIS is described along with an analysis of the implications of using competencies as a fundamental unit for describing curricula. Secondly, we describe the specific two-dimensional content model that was developed for the KOMPIS project. Finally, we describe some of the major results from this experimental teaching and analyse their implications for curriculum development (cf. Højgaard \& Sølberg, submitted conference paper). 


\section{Background}

During the last 3-4 decades, mathematics and science teaching in many parts of the world has gradually been reformed towards describing the curricular ambitions as mastery of a combination of subject matter and more practice-oriented ambitions (cf. the analysis of examples of such processes in, e.g., Bergqvist \& Bergqvist, 2017; Innabi \& Sheikh, 2006). In Denmark, as well as in several other countries, these practice-oriented ambitions have been described by means of different kinds of competencies (Niss et al., 2016). Politically, this conceptual focus is partly due to the initiation of what has since been called the Bologna process, aimed at making transfer of educational merits between countries of the EU easier (European Ministry of Education, 1999). To accomplish this a unified description of educational standards was needed, and it was decided to describe these standards in terms of competencies.

Alongside this political process, there has been theoretical and practical development of competencies as an educational concept. One of the most significant developments was the appointment of a workgroup called Description and Selection of Competencies (DeSeCo). In their final report, they formulated a well-conceived and holistic definition of the term and presented their recommendations for "key competencies for the good life and the well-functioning society" (Rychen \& Salganik, 2003).

\section{Syllabusitis}

Analytically, another educational approach to the concept of competence can arise from asking the question (cf. Blomhøj \& Jensen, 2007, p. 46-47, which this and the next section is based on): What constitutes a subject, e.g. mathematics or biology? The answer is: Many things, of course, but we feel convinced that everyone will agree, that mathematics at least has to do with certain objects, concepts and proceduresthat we (tautologically) consider as mathematical. And a similarly case can be made for the various science subjects. Many people use this relation to subject matter to characterize the subject. "Mathematics is the subject dealing with numbers, geometry, functions, calculations, etc." and "biology is the subject dealing with animals, plants, evolution, ecology, etc." is not a rare type of answer to the questions of what constitutes mathematics and biology respectively.

What, then, does it mean to master a subject? With reference to the above, it is tempting to identify mastering mathematics/biology with proficiency in mathematical/biological subject matter. However, this belief if transformed into educational practice is severely debilitating for students' ability to make reason of the subjects and to apply them in future contexts. The debilitating effect is potentially severe enough that the phenomena has been given a name that evokes images of a disease, namely syllabusitis (Lewis, 1972; Jensen, 1995). Syllabusitis represents the condition that occurs, when curriculum goals are prescribed in a way that fails to acknowledge important aspects of what it means to master a subject, e.g. mathematical reasoning or conducting scientific investigations to mention a few. Most curricula are based on ambitions that the aims of a given subject are to make students better at the given subject. However, a curriculum infected by syllabusitis tends to focus only on the ability to reproduce subject matter and therefore fails to set an appropriate level of ambition and puts the teacher in position where they struggle to cover the prescribed subject matter. Hence, there isan important challenge of describing curricular goals as masteryof a given subject in a way that can prevent syllabusitis.

\section{The KOM project, competency and mathematical competencies}

The issue of syllabusitis was one of the main concerns to be addressed when Mogens Niss proposed to conceptually define mathematical competencies as a tool for developing mathematics education (Niss, 1999). The so-called KOM project (Niss \& Jensen, 2002), running from 2000-2002, thoroughly introduced, developed and exemplified mathematical competencies at all levels of education from 
primary school to university (cf. Niss \& Højgaard, to appear) for a presentation and analysis of the project and an English translation of the original report).

The definition of the term "competence" in the KOM project (Niss \& Jensen, 2002, p. 43) was semantically identical to the one we use: Competence is someone's insightful readiness to act in response to the challenges of a given situation (cf. Blomhøj \& Jensen, 2003). In definite form, a mathematical competency is consequently defined as someone's insightful readiness to act in response to a certain kind of mathematical challenge of a given situation, and then identify, explicitly formulate and exemplify a set of mathematical competencies as independent dimensions spanning full range of mathematical competence. The core of the KOM project was to carry out such an analysis, of which the result is visualized in condensed form in figure 1.

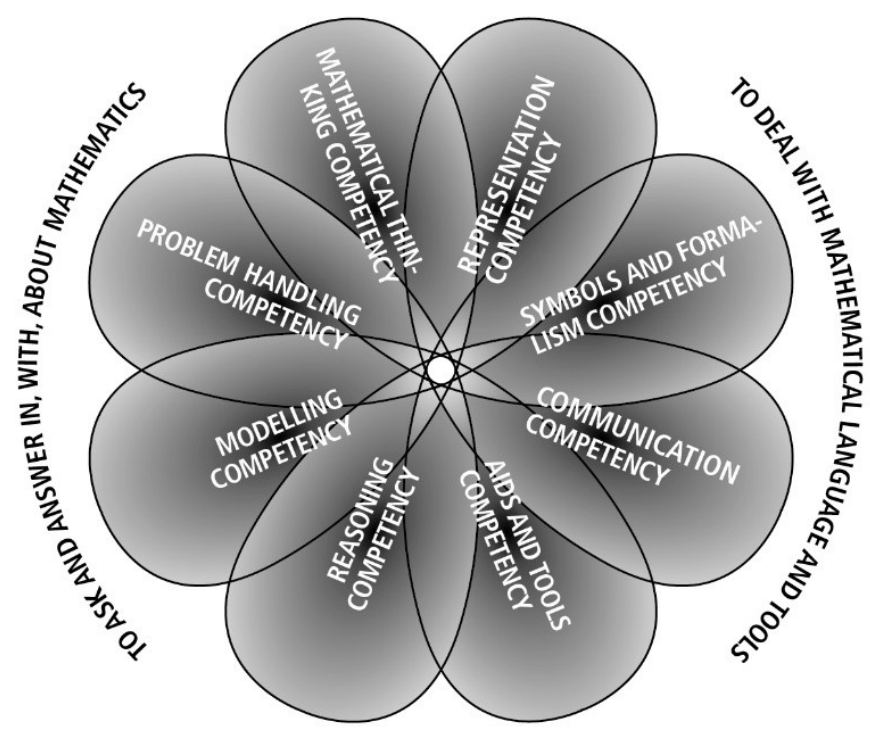

Figure 1. A visual representation - the "KOM flower" - of the eight mathematical competencies presented and exemplified in the KOM report (Niss \& Højgaard, to appear).

Such a set of mathematical competencies has the potential of replacing the syllabus as the focus of attention when working with the development of mathematics education, simply because it offers a vocabulary for a focused discussion of what it means to master mathematics (Jensen, 2007).

\section{A two-dimensional content model}

Following the approach of the $\mathrm{KOM}$ project, the endeavour to incorporate subject specific descriptions of competencies in mathematics curricula should primarily be guided by an attempt to fight syllabusitis. In this perspective, it was important to focus on the interplay between subject specific competencies and the subject matter traditionally described in the syllabus.

In the KOM report the proposal for such an interplay is to separate subject specific competencies and subject matter areas as two independent dimensions of content (Niss \& Højgaard, to appear). Subsequent research and development work (Jensen, 2007) supported the importance of such an 
approach to curriculum development. This work also pointed to a general hypothesis that a curriculum systematically used to combine competencies and subject matter could support goaloriented planning of teaching that would alleviate syllabusitis. The model in figure 2 was proposed as a representation of the core of mathematics in the revised National Standards for mathematics of 2009 (Undervisningsministeriet, 2009).

\begin{tabular}{|c|c|c|c|}
\hline $\begin{array}{l}\text { Subject matter area } \\
\begin{array}{l}\text { Subject specific } \\
\text { competencies }\end{array}\end{array}$ & $\begin{array}{l}\text { Numbers and } \\
\text { algebra }\end{array}$ & Geometry & $\begin{array}{l}\text { Statistics and } \\
\text { probability }\end{array}$ \\
\hline Math. thinking comp. & & & \\
\hline Math. problem handling comp. & & & \\
\hline Math. modelling comp. & & & \\
\hline Math. reasoning comp. & & & \\
\hline Math. representation comp. & & & \\
\hline Math. symbols and form. comp. & & & \\
\hline Math. communication comp. & & & \\
\hline Math. aids and tools comp. & & & \\
\hline
\end{tabular}

Figure 2. A two-dimensional model for description of the content of grade k-9 mathematics teaching (Højgaard et al., 2010, p. 15).

From a curricular perspective, the defining point of such a two-dimensional content model is that the subject specific competencies (e.g. modelling competency) can function as "the missing link" between the overarching purpose of an education and a concrete syllabus, by pointing out what types of challenges the students must be able to act in relation to.

It should be noted, that there had not been a development within science education in Denmark towards a common conceptualisation of competencies akin to the more comprehensive process that the mathematics curriculum had undergone. The closest approximation to a description of science competencies were the four overarching competencies described in the so-callledFNU report (Andersen et al., 2003). These descriptions comprised the conceptual starting point for the science group going into KOMPIS. However, as we shall explain later, the science group had to develop a functional understanding of what constituted science competencies before applying the twodimensional model approach in science.

\section{The KOMPIS project}

KOMPIS was a development project based on experimental teaching that was meant to explore whether the two-dimensional approach in figure 2 would enable teachers to make their teaching competency-oriented. The project group included 16 teachers from four schools together with three university researchers and three teacher educators split into three subject groups - mathematics, science and Danish. The groups had three-hour meetings at alternating schools once every month to discuss the teachers' experience and reflections regarding their competence-based lesson plans and the experimental teaching they tried out between meetings. Furthermore, all participants met 
(including representatives from the municipality) twice a year for full-day seminars to exchange experiences across subjects.

In addition, several initiatives were included in the design to support the ongoing professional development among the teachers involved. This included securing administrative support from the municipality as well as school leadership to ensure that the teachers had ample opportunity to reorganise their teaching and that they were not penalised for deviating from local teaching plans. In addition, leadership involvement was deemed essential to the long-term effects of the project and for the possibilities of disseminating good teaching practices after the conclusion of the project.

\section{Results}

Planning competency-oriented teaching. The common distinction between planning and organization of teaching is useful for describing some of the results of the KOMPIS project. In doing so we will follow Larsen, 1969 and consider planning of teaching as the process of making decisions regarding the content of the teaching, whereas organization of teaching deals with selecting appropriateteaching methods(relative to the content and the learning ambitions associated with it) and making decisions regarding the course of the teaching. In short, we might describe it as the difference between answering the question "What are the students to learn?" and "What are the students to do?"

In this sense of the phrase, planning of teaching inevitably boils down to an endeavour with one dominating dimension: Time. Since time is a scarce resource when teaching takes place within a formal educational system like compulsory schooling, a more interesting version of the question mentioned above is: When are the students to learn what?

In this light, it is of little surprise that introducing two-dimensional content models as shown in figure 2 may pose a challenge to the planning of teaching. One of the consequences of this approach is that it makes didactical considerations necessary when planning from a two-dimensional content structure to a one-dimensional yearly teaching plan. Planning of competency-oriented teaching is ideally about creating a connection between the two dimensions in such a way that the work with a given subject matter area can be explained and motivated by development of competencies, which make the students able to handle new types of situations or known situations in a more competent way. This often requires more prolonged and successive teaching making it necessary to plan teaching in modules wherein the students get to build competency.

This approach can be modelled by dividing the year up into more-or-less distinct modules and deciding early on which areas of subject matter, competencies or combination of the two to focus on, cf. the modelling of this approach in figure 3. This model can function as a planning and reflection tool for teachers as well as a model that teachers can use when they discuss what the objectives of a given teaching session is with colleagues and students (Højgaard, 2010). 


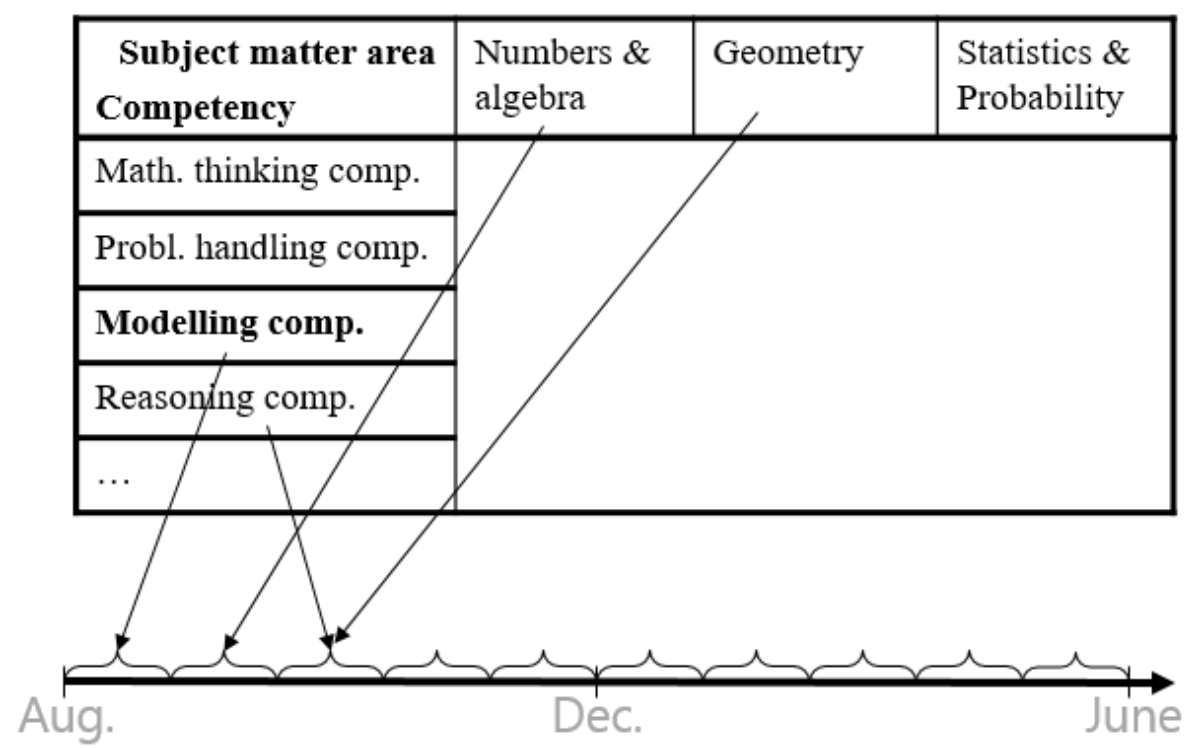

Figure 3. The two-dimensional model used as a tool for planning of teaching by creating modules of some weeks in duration, each appointed with explicitly stated learning objectives consisting of subject specific competencies and/or objectives related to specific subject matter.

An important part of implementing competency objectives in teaching turned out to be linked to planning for extended periods of time, where students and teachers could focus on a few selected competency objectives. KOMPIS was designed to ensure that teachers included such periods in their yearly planning from year two of the project. When the mathematics teacher involved were interviewed subsequently, they assessed the explicit use of the model in figure 3 as a planning tool as challenging, but also constructive and meaningful. Challenging because the representation of competencies as a separate dimension in the model forced them to be explicit about their ways of thinking and working with these new kinds of objectives. Constructive because the model turned out to be a comprehensible tool for reflections when planning their teaching. Meaningful because they experienced the mathematical competencies as a way of making some of their more fundamental ambitions as mathematics teachers explicit.

Organising competency-oriented teaching. By dividing the year up into more-or-less distinct modules, the dominant organizational approach used by the teachers in the KOMPIS project was project periods where the students could work on a selected competency objective. This was a way of establishing the didactical contract, which is a term for how a teaching situation in any form of institutionalized educational context is formed by an implicit contract between the teacher and the students (Brousseau, 1997). The didactical contract is a metaphorical mutual understanding and agreement that evolves in a given classroom through the organization of the teaching and the interactions between the teacher and the students. By using a more-or-less consistent template for the project periods, the students and teachers became familiar with the process and thereby knew what was expected of them. This enabled students and teachers to work together to achieve the competency objectives selected for the project period.

In the mathematics group, one teacher in particular was followed closely by observing and video recording about half of the approximately 250 mathematics lessons she taught in grades eighth and nine throughout the last two years of the project. Her project periods were very deliberately and explicitly organized with the following general characteristics:

a) The teacher decided on a given mathematical competency objective to focus on for the project period. 
Six projects were oriented towards the mathematical modelling competency and two towards mathematical reasoning competency.

b) Approximately, one week was spent on helping students develop an understanding of the given competency objective.

An example of this was that in the first project focusing on mathematical reasoning, where the teacher let the students spend the first week gaining different experiences with mathematical reasoning by alternating between short tasks that required students to use mathematical reasoning and group discussions about their reflections. This led to the development of a model that presented the students ideas about central elements involved in mathematical reasoning (Sølberg et al., 2015).

c) Once the class had reached a common understanding of the given competency, each project group was required to come up with relevant problems involving the given competency. They then spent the rest of the allotted time working on problems through which they developed the given mathematical competency.

For example, one group of students chose to work on the mathematical reasoning involved in solving and producing Sudokus, while another group worked on developing simple mathematical proofs.

The process ensured that students and teacher reached a mutual understanding of a competency objective before the students were challenged to find ways of developing it. Another advantage was that the students became familiar with the template, and after the first couple of projects, they did not need as much instruction during the project work and gradually gained significant ownership of the process.

A similar template was implemented for the science group, but due to practical difficulties it was not possible to secure sufficient consecutive lessons to carry out even shorter projects. Practical difficulties included teachers having only one to three lessons a week with the students (as opposed to five lessons a week for mathematics) and frequent cancellations due to school events, teacher seminars, illness and the like. Instead, the science teachers attempted to focus their teaching on a given science competency objective for up to eight weeks at a time. However, without being able to conduct projects, the students did not have the same opportunities to play an active role in developing their competencies as was observed in the mathematics classes.

Clear and distinct competencies. As mentioned above, the mathematics group had a strong vantage point since the list of competencies derived from the KOM report were already one of the main constituents of the National Standards for compulsory mathematics education. This meant that they already had eight theoretically well-defined competencies to work with.

The science group also had a predefined set of competencies from the FNU report(Andersen et al., 2003). However, it quickly became apparent that the descriptions of each of the four science competencies in the report were difficult to differentiate from each other in practice, as there was significant overlap between them. This was especially the case with the representation and modelling competencies. The group therefore found that the descriptions were not very operational in relation to helping the teachers plan their teaching in the science. Because the report's definitions were not directly usable, it became an ongoing challenge to unfold and operationalise the science competencies, and the resulting model of science competencies ended up being one of the most important results from the science group.

At the end of the project the group had developed the model in figure 4 to describe science competencies based upon a pragmatic division of the competencies in relation to typical activities in science (see Christiansen et al., 2013 for more details about the model). The model developed by the science group kept the perspective and empirical competencies, since these were immediately 
recognizable for the teachers. Representation competency ended up as a part of the modelling competency which was also retained.

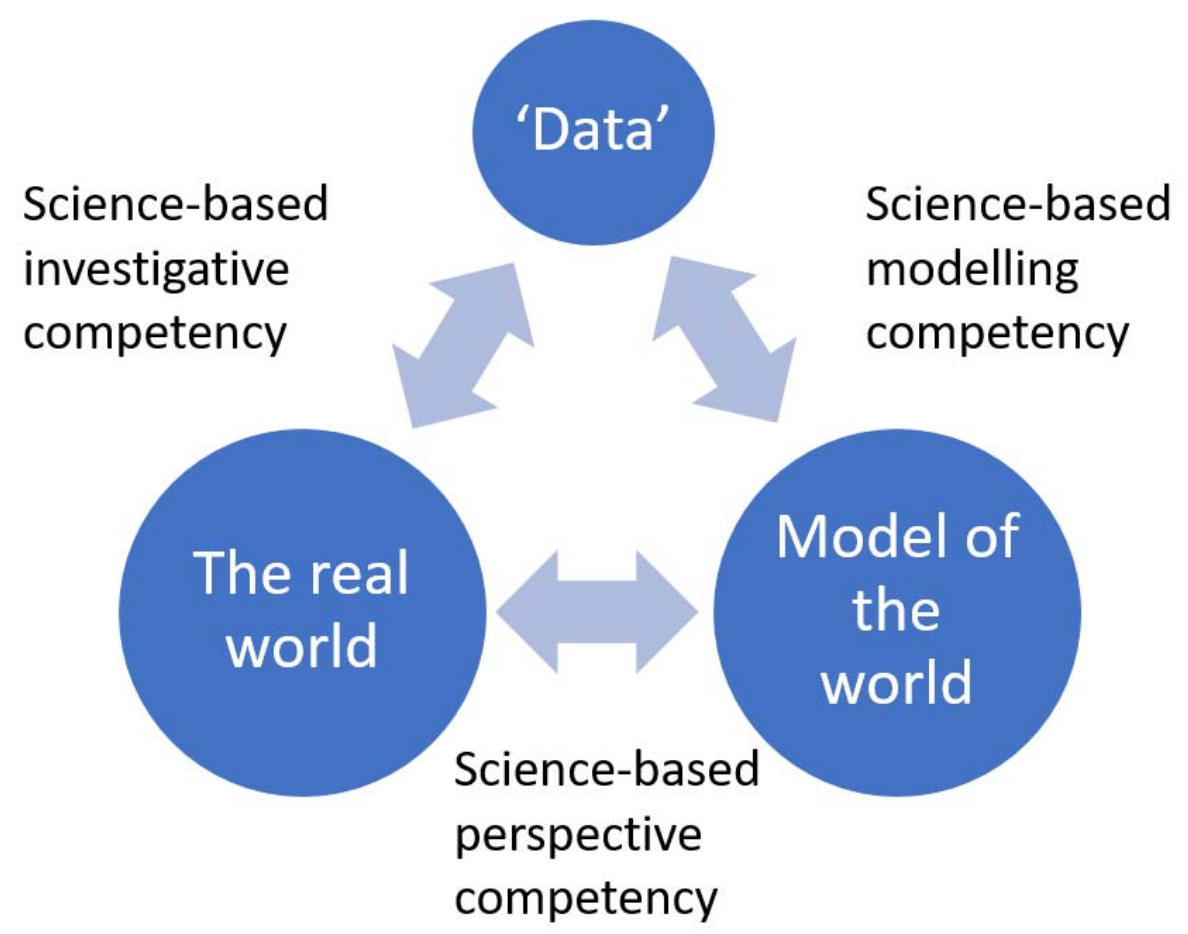

Figure 4. Model of science competencies illustrating the connection between the different competencies and how they relate to different elements of teaching science.

The teachers in the science group found the model useful in distinguishing between the three competencies. One of the conclusions of the science group's discussions was that it was beneficial to focus on one competency at a time as opposed to trying to design teaching that could cover a lot of objectives.

There were quite a few discussions in the group about a possible fourth competency which related to students' ability to communicate with and about science (including using scientific arguments and correct scientific terminology). This fourth communication competency could be interpreted as an underlying competency which could be thought of as a prerequisite for the other competencies to be expressed. Thus, the model was not refined to a point where all members of the group agreed on the interpretation of it, but it served the important purpose of establishing a common language regarding the different science competencies which made it possible for the group to discuss different examples of teaching.

Competency-oriented teaching. One of our assumptions going into the KOMPIS project was that the biggest challenge for the teachers was going to be the transposition of specific competency objectives into teaching practices. As it turned out, the greatest challenge was getting the teachers to think in terms of competency objectives in the first place. This fundamental difference between planning teaching based on clear objectives for what the students should be able to do instead what subject matter they need to know posed a radical challenge for the teachers. However, once the teachers had become familiar with competency-oriented teaching, it changed their perspective on teaching, the way they communicated about teaching, and ultimately their teaching practices. 
An example of how the teachers' growing understanding of the subject specific objectives manifested itself in their teaching practices, was when they in the groups expressed a need to allow the students more "time to simmer". The teachers found themselves becoming less prone to interfere immediately when the students became frustrated and/or despondent. The teachers realised that the students learned more when they were forced to find their own solutions, which was a consequence of the shifting teacher focus from teaching certain concepts towards developing student competencies.

This shift in focus was not something that happened quickly or spontaneously. It was largely made possible by the long-term close collaboration in KOMPIS. Only after more than a year of monthly meetings between teachers, teacher educators and researchers in the subject groups did the teachers start to express an earnest understanding of competency objectives and thereby also how to teach in a competency-oriented way.

Competency goals as a tool for communication. The focus on specific competency objectives changed the way the teachers communicated with each other within and across subject boundaries. By the end of the project, teachers in all three subject groups could identify and discuss subject specific competencies in a language of first order as described by Høines (Høines, 2006, s. 76-80). This meant that the competency objectives (and related concepts) had become a natural part of their mutual communication when they discussed ambitions for and the purpose of different lesson plans.

The benefit of this was two-fold. Firstly, discussing and interpreting the different subject specific competency objectives helped the teachers familiarise themselves with the aims for teaching they represented. Having the opportunity to discuss these with other teachers created a mutual understanding and sense of ownership with the competency objectives even though there were individual variations in the teachers' understanding. The individual interpretations helped keep the monthly discussions relevant and honed the teachers' understanding and ability to communicate exactly what they meant by the different subject specific competency objectives.

Secondly, the introduction of clear and distinctive competency objectives enabled the teachers to discuss teaching examples. Throughout KOMPIS, the teachers were continually matching their understanding of with actual planning, execution and evaluation of teaching. This helped the teachers transform their understanding of the subject specific competency objectives into practice.

An example of this was when two science teachers recorded a teaching session on video in order to analyse students' learning. The students experimented with induction in groups after a short introduction designed to allow the students opportunity to explore the phenomenon. During their experimentation, one of the teachers recorded the students and asked them questions while they worked. Afterwards, the teachers watched the videos together and selected video clips that the science group discussed at the following meeting. The video clips formed the basis for discussion of which competencies the students exhibited signs of and how the teaching enabled or inhibited their development of these competencies.

The dilemma of teaching directed autonomy. One of the challenges of using competency objectives in teaching was balancing student autonomy with curricular goals. The teachers found that they had to create opportunities for students to work autonomously to some extent if they wanted students to develop the type of competencies that KOMPIS aimed for. At the same time, they felt a need to define subject specific objectives that met the National Standards. This dilemma has been described as the dilemma of teaching directed autonomy (Jensen, 2007).

Finding a way to handling this dilemma was a focus area in one of the KOMPIS classes. The mathematics teacher in this class planned several projects together with one of the authors with the 
explicit ambition to develop the students' mathematical modelling competency and mathematical reasoning competency. As explained above, each project began with a week focusing on developing the students' understanding of the chosen competency. Once the students understood what could constitute the chosen competency (e.g. modelling competency), they could use this understanding to define problems that they wanted to work on in relation to the chosen competency. In this way, the students became jointly responsible for reaching the objectives set up by the teacher and the dilemma was resolved. Getting the students involved in discussing subject specific competency objectives made it possible to align student autonomy and teacher defined objectives (see Højgaard, 2010). But this approach only worked when teachers were focussed on few and distinct competency objectives at a time.

\section{Curricular perspectives}

Using KOMPIS as a specific case, we asked: How can we describe curriculum in a way that enables teachers to structure their planning in a manner that focusses on student competence? The answer to this question lies in distinguishing between competencies and subject matter as two independent dimensions of content descriptions as examplified by the teaching experiments developed through KOMPIS. By following the model in figure 2, teachers can avoid syllabusitis and at the same time formulate competency-oriented learning objectives that enables students to develop competency. Using this approach, KOMPIS teachers were able to plan their school year in a way that allowed them maintain focus on a few key subject specific competencies and thereby create the necessary conditions for sustained development of student competence. In addition, being able to focus on a few learning objectives at a time enabled the students to better understand the meaning behind the learning objectives which in turn enabled them to pursue them more independently.

To formulate specific competency-oriented learning objectives, however, teachers need clear and distinct competency descriptions that they can use in their communcation with other teachers as well as students.

\section{Final remarks}

Our goal behind the KOMPIS project was to engage teachers in developing an approach to competency-oriented teaching that was not only meaningful but also practical from a teachers perspective. The experiences from KOMPIS have come to influence national curriculum revisions. Both the two-dimensional description of mathematics content and the competency descriptions for science developed through KOMPIS were incorporated into the National Standards (Undervisningsministeriet, 2014). More specifically, the three KOMPIS science competencies as well as a communication competency became the common objectives ofall compulsory science teaching in Denmark.

Thus, Danish mathematics and science teachers are currently obligated to use two-dimensional subject-specific goal descriptions in planning their teaching. However, the 2014 reform also made all possible combinations of the two-dimensional structure mandatory for teachers. The refom thereby failed to impart teachers with more professional autonomy to plan their teaching in ways that could combate syllabusitis.

Following push back from teachers and researchers, the reform was revised in 2018 so that the mandatory combinations of competency goals and subject-specific content became optional. Thereby, Danish National Standards have evolved into the kind of curricular setup that was the premise for KOMPIS, creating opportunities for a teacher to begin adapting to competency oriented teaching. 


\section{References}

Blomhøj, M., \& Jensen, T. H. (2003). Developing mathematical modelling competence: Conceptual clarification and educational planning. Teaching mathematics and its applications, 22(3), 123-139.

Blomhøj, M., \& Jensen, T.H. (2007). What's all the fuss about competencies? Experiences with using a competence perspective on mathematics education to develop the teaching of mathematical modelling. In W. Blum, P.L. Galbraith, H.-W. Henn, \& M. Niss (Eds.), Modelling and applications in mathematics education - The 14 ${ }^{\text {th }}$ ICMI-study (45-56). New York, US: Springer.

Bergqvist, E., \& Bergqvist, T. (2017). The role of the formal written curriculum in standards-based reform. Journal of Curriculum Studies, 49(2), 149-168.

Brousseau, G. (1997). Theory of didactical situations in mathematics.Dordrecht, NL: Kluwer.

Christiansen, J. L., Hansen, N. J., \& Madsen, J. (2013). KOMPIS - Kompetencemål i praksis: Dansk, matematik og naturfag 2009-2012 [KOMPIS - Competency objectives in practice: Danish, mathematics and science 2009-2012]. Holbæk, Denmark: University College Sjælland.

European Ministry of Education. (1999). The Bologna declaration of 19 June 1999. https://www.eurashe.eu/library/modernisingphe/Bologna_1999_Bologna-Declaration.pdf, (accessed September 2018)

Høines, M. J. (2006). Begynneropplæringen: fagdidaktikk for barnetrinnets matematikkundervisning [Beginner training: Pedagogical content knowledge for mathematics teaching of children] (2nd ed.). Bergen, Norway: Caspar forlag.

Højgaard, T. (2010). Communication: The Essential Difference Between Mathematical Modeling and Problem Solving. In R. Lesh, P. Galbraith, C. Haines, \& A. Hurford (Eds.), Modeling Students' Mathematical Modeling Competences (pp. 255-264). New York: US: Springer.

Højgaard, T., Bundsgaard, J., Sølberg, J., \& Elmose, S. (2010). Kompetencemål i praksis - foranalysen bag projektet KOMPIS [Competency objectives in practice - initial analysis for the KOMPIS project]. MONA:Matematik og Naturfagsdidaktik, 3, 7-29.

Højgaard, T., \& Sølberg, J. (submitted). Competencies and Curricula: A case Story of Two-dimensional Curriculum Development. Paper submitted for presentation at the conference CERME 11 in Utrecht, The Netherlands, February 2019.

Innabi, H., \& Sheikh, O. E. (2006). The change in mathematics teachers' perceptions of critical thinking after 15 years of educational reform in Jordan. Educational Studies in Mathematics, 64(1), 45-68.

Jensen, J. H. (1995). Faglighed og pensumitis [Subject understanding and syllabusitis]. Uddannelse, 9, 464-468.

Jensen, T. H. (2007). Udvikling af matematisk modelleringskompetence som matematikundervisningens omdrejningspunkt-hvorfor $i k k e$ ?[Development of mathematical modelling competency as the center point of teaching mathematics - why not?] (Doctoral dissertation). Roskilde, Denmark: University of Roskilde.

Larsen, C. A. (1969). Didaktik: om didaktikken som planlægningsvirksomhed og om dens systematiske placering i pædagogikken [Didactics: on didactics as a means for planning teaching and its systematic place in relation to pedagogy]. Copenhagen, Denmark: Royal Danish School of Educational Studies.

Lewis, J. L. (1972). Teaching School Physics. A UNESCO Source Book. Baltimore, Maryland, USA: Penguin Books.

Niss, M. (1999). Kompetencer og uddannelsesbeskrivelse [Competencies and descriptions of education]. Uddannelse, 9, 21-29.

Niss, M., \& Højgaard, T. (to appear). Mathematical Competencies in Mathematics Education: Past, Present, and Future. New York, US: Springer.

Niss, M., \& Jensen, T. H. (2002). Kompetencer og matematiklæring: Idéer og inspiration til udvikling af matematikundervisning $i$ Danmark [Competencies and mathematical learning: Ideas and inspiration for the development of mathematics teaching in Denmark]. Copenhagen, Denmark: Ministry of Education.

Niss, M., Bruder, R., Planas, N., Turner, R., \& Villa-Ochoa, J. A. (2016). Survey team on: conceptualization of the role of competencies, knowing and knowledge in mathematics education research, ZDM, 48(5), 611-632.

Rychen, D. S., \& Salganik, L. H. (2003). Key Competencies for a Successful Life and a Well-Functioning Society. Cambridge, MA, US: Hogrefe \& Huber.

Sølberg, J., Bundsgaard, J., \& Højgaard, T. (2015). Kompetencemål i praksis - hvad har vi lært af KOMPIS? [Competency objectives in practice - lessons learned]. MONA: Matematik og Naturfagsdidaktik, 2, 46-59.

Undervisningsministeriet. (2009). Fælles Mål 2009 - Matematik [National Standards 2009 - Mathematics]. Copenhagen, Denmark: Ministry of Education.

Undervisningsministeriet. (2014). Fælles Mål 2014 [National Standards 2014]. https://www.emu.dk/omraade/gsk-1\%C3\%A6rer, (accessed September 2018) 